chev's personal difficulty is that he needs his Party office to secure whatever reforms may be effected by the nowelected Supreme Soviet against erosion from within. But, by continuing to hold it, he becomes tarred by the antiParty brush. A year ago, it seemed that he might be ready to change horses, yet he seems less effective a reformer as president than he was before. The explanation is that the Party, whose economic planning is the source of the Soviet Union's economic collapse, remains also the source of other proposals for reform. And they are consistently inadequate.

Bush could not have helped resolve that problem, which is Gorbachev's, but he could have done more to help the process of economic change in the Soviet Union. The two governments signed a trade pact that will eventually assist Soviet access to US markets and US investment in the Soviet Union, but only when the Soviet Union can satisfy the US Congress on Lithuania and emigration policy. That is too long to wait, both for the worsening plight of the Soviet people and the long-term interest of the United States that US capital and companies should play a decisive part in the industrial development of the Soviet Union. There will be many in the United States who will be kicking themselves, some years from now, when it becomes plain that West Germany has been the agent of economic change in Eastern Europe and that the United States has missed the boat in its natural territory further East. But that is not the worst case, which is rather that economic chaos may provoke civil chaos and then military government in the Soviet Union, on the cards since the beginning of the year. Where would the stillincomplete START treaty then stand?

\section{University lottery}

The new system by which British universities must bid against each other for students is a game of chance.

BRITISH universities, too often reviled by their government for their inclination to count angels on the heads of pins, are being required by their new paymaster (the Universities. Funding Council, or UFC), to engage in precisely such a task - that of playing against each other in a game of poker whose rules are unknown. The game (see page 468) is that in which universities are required to say in the next few weeks what public subvention they would require to accommodate how many students in which fields of study. The only rule made public is that the cost per student must not exceed a 'guide price' set by UFC, which varies from one field to another.

UFC's objective is to win "economies of scale" - or lower ratios of teaching staff to students. Plainly these are achievable. It must always be possible to cram more bodies into lecture rooms, and the cost of operating laboratories can always be cheapened, perhaps by using graduate students as demonstrators. Universities providing individual instruction can similarly hope to reduce marginal costs by teaching people in larger groups. That is the declared logic of the new competition, in which the marginal cost of teaching must always be zero or something like it. The other side of the coin, of course, is the quality of marginal cost teaching, with which UFC seems less concerned.

There has been some dark muttering among vicechancellors about a secret agreement to enter bids for students at UFC's guide prices, but that must be a risk. Which university can be sure that all its potential competitors will follow the same line? But those tempted to go for growth by entering bids in chosen fields below the appropriate guide prices may find that other universities have done the same in the same fields. But those are only some of the hazards. What will happen when the bids go in, and are adjudicated? UFC will eventually decide which universities are allotted which student numbers, but will presumably make decisions in the light not merely of the cost of educating people in particular fields but of that of compensating universities for closing whole departments whose bids have been undercut elsewhere. But how will that be done, while universities are still supposedly autonomous? The bidding process may seem to universities like a poker game, but the outcome will be more like that of a lottery.

\section{British beef banned}

Those who will not eat British beef must be prepared to settle for a European veterinary service.

Тнат the West German government last week followed the French in banning imports of British beef is an offence against the spirit (and the letter) of the Treaty of Rome on which the European Communities are founded, but is no great surprise. People in France are worried by reports of bovine spongiform encephalopathy (BSE) in British cattle, and by fears that they or their cattle will thereby be contaminated. Some years ago, the British banned the import of French turkeys on the grounds that some flocks were infected by Newcastle disease virus.

British ministers are right to say that the latest affair is a test of European governments' will to carry through the single market project due to become a reality on 1 January 1993. So it is, but not quite in the way intended. The British government's case is that the spread of BSE in Britain is adequately contained by the precautions so far taken, and that "British beef is safe". Whether or not people in Britain are reassured, those elsewhere may well distrust assertions that disputed practices can be absolutely safe. Ideally, the Common Agricultural Policy (which will be spending large sums of European taxpayers' money on supporting British beef prices) would have its own veterinary service capable of reassuring all European consumers. (Instead, it has an advisory committee.) It will be a real test of the European will to be European that such arrangements would be welcome.

NATURE $\cdot$ VOL $345 \cdot 7$ JUNE 1990 